\title{
The Role of Bacteria and Yeasts in AIDS
}

\author{
Vladimír Zajac ${ }^{1,2}, Z^{2}$ zana Adamcikova ${ }^{1}$, \\ Vladimir Holec ${ }^{2,3}$, Katarina Hainova1, Viola Stevurkova1, \\ Lenka Wachsmannova ${ }^{1}$ and Vladimir Krcmery ${ }^{4}$ \\ ${ }^{1}$ The Cancer Reasearch Institute, Department of Cancer Genetics, SAS, Bratislava, \\ ${ }^{2}$ Comenius University, Medical Faculty, Bratislava, \\ ${ }^{3}$ University Children's Hospital, Banska Bystrica, \\ ${ }^{4}$ St. Elizabeth University College of Health and Social Sciences, Bratislava, \\ Slovak Republic
}

\section{Introduction}

Human immunodeficiency virus type I (HIV-1) is widely accepted as the cause of AIDS. It is also believed that HIV-1 itself is sufficient to cause immunodeficiency and to destroy parenchyma cells inducing widespread organ failure. Despite the unquestionable success in diagnosis and therapy of this disease, there are many unanswered questions. The substantial argument of this predication is the fact that it is still not possible to stop the worldwide pervasion of AIDS, especially in Africa and Asia. Without giving answers to all these questions a more successful treatment of patients cannot be expected. The fight against this disease is challenging and should be realized in a more complex manner, overcoming all the taboos and dogmas surrounding the disease. It is necessary to deliberate other potential factors, not only HIV, which may take part in this disease.

Plasma HIV RNA is dramatically reduced in HIV/AIDS patients treated with highly active antiretroviral therapy (HAART), but residual viral replication is detected after suppression of plasma viraemia (Chun et al., 2000; Cusisni et al., 2004). It has also been expressly proven that various forms of HIV reservoirs persist in practically all patients receiving HAART (Finzi et al., 1997; Siliciano et al., 2003). The range of viral reservoirs in the human body is probably very much wider, as claimed in recent studies. Reservoirs were detected in macrophages and other cells of the blood system, in which even very effective HAART was not able to eliminate the virus. HIV persists in peripheral blood mononuclear cells despite sustained, undetectable plasma viraemia resulting from long-term antiretroviral therapy (Veazey et al., 1998; Brenchley et al., 2004). The source of persistent HIV in these infected persons remains however unclear.

Over the last period of time AIDS research has been focused on the gut and other mucosal tissue, and not blood, as the major site of HIV infection and CD4+ T cells loss (Veazey et al., 2005). Mattapallil and Li both showed that the major focus of destruction of memory CD4+ $\mathrm{T}$ cells by simian immunodeficiency virus (SIV) is in mucosal cells, where most $\mathrm{T}$ cells expressing CD4 and CCR5 with a "memory" phenotype reside (Mattapallil et al., 2005; Li et al., 2005). The loss of $\mathrm{CD}^{+} \mathrm{T}$ cells in the intestine coincided with productive infection of 
large numbers of mononuclear cells at this site (Veazey et al., 1990). These recent findings support the idea that the mucosal and intestine immune system is the major site of viral replication, persistence and CD4+ T cells loss in HIV-1 infected persons (Guadalupe et al., 2006; Dandekar et al., 2007; Ling et al., 2007, 2010; Lackner et al., 2009; Hatziioannou et al., 2009). HIV-1 has been also detected in bowel crypt cells and the lamina propria from patients with gastrointestinal symptoms (Nelson et al., 1988). The pathogenesis of HIV infection is presumably centered on these mucosal viral "target" cells. Since these cells are in close vicinity to intestinal bacteria, the idea has been raised that bacteria may also be involved in AIDS pathogenesis.

This interest in investigating bacteria and mycoplasma was also supported by Montagnier's finding, confirmed by Shyh-Ching Lo, that mycoplasma is a very important "co-factor" which accelerates the progression of HIV infection in AIDS patients (Montagnier, 1986; Lo et al., 1991). And finally, Cantwell and Broxmeyer pointed out that there is a very close relationship between bacteria and cancer, resp. AIDS (Cantwell, 1983, 1993; Broxmeyer \& Cantwell, 2008).

\section{Molecular biology analysis of bacteria and yeasts of HIV positive patients}

\subsection{Dot blot DNA hybridization.}

To verify this idea, bacterial DNA isolated from the gastrointestinal tract and blood DNA of 51 AIDS patients and 10 healthy subjects were tested for the presence of HIV-1 sequences by colony and dot blot hybridization (Zajac et al., 2005, 2006, 2007, 2011). In dot blot hybridization, the lymphocyte/bacterial DNA of American and Slovak HIV/AIDS patients were in most cases positive (Figure 1). Of 27 patient samples, 23 lymphocyte DNA and 20 bacterial were positive, with respective $85 \%$ and $74 \%$. Yet positivity of all the 41 patients tested was approximately the same. The selected patients 23, 33, 44, 78, 30, P1 and P15 are localized as follows: patient 23 in line 2 - position 1,2; patient 33 in line 1 - 5,6; patient 44 in line $4-3,4$; patient 78 in line $6-1,2$; patient 30 in line $7-1,2$; patient P1 in line $7-3,4$ and patient P15 in line $7-5,6$. The intensity of the hybridization signal was in correlation with the origin of the probes used, the signal of human samples was more intensive with the applied human probes and vice versa for bacterial probes (data not shown). These findings suggest some differences in sequences between the two sources of material. The hybridization signals of samples from patients 96, 83, 62 (line 3, position 5, 6; line 4, position 1, 2; line 2, position 5,6) were not intensive either in lymphocyte or bacterial DNA. These patients were classified as A1 stage of their CDC clinical category with CD4 ${ }^{+}$around $400 / \mu 1$. The obtained results are in correlation with the common usage of $68 ; 69$ primers in AIDS diagnostics. The hybridization signal was not detected in samples of control subjects, with the exception of samples from one subject (line 12, position 5,6).

Bacteria and yeasts from the respiratory tract (nose, pharyngeal swabs) were isolated from 39 Cambodian and 28 Kenyan HIV-positive children. The majority of microbes were characterized as Staphylococcus aureus, Klebsiella pneumoniae and Candida albicans. In some cases, E. coli, Streptococcus pyogenes, Proteus mirabilis and Candida tropicalis were identified. Bacteria and yeasts of 16 Cambodian ( $41 \%)$ and 8 Kenyan $(31 \%)$ children were found to be positive in colony and dot-blot DNA hybridization (17). Bacteria and yeasts from the respiratory tract of $41 \%$ of Cambodian (Figure 2) and 31\% of Kenyan HIV-positive children bear HIV-like sequences. 


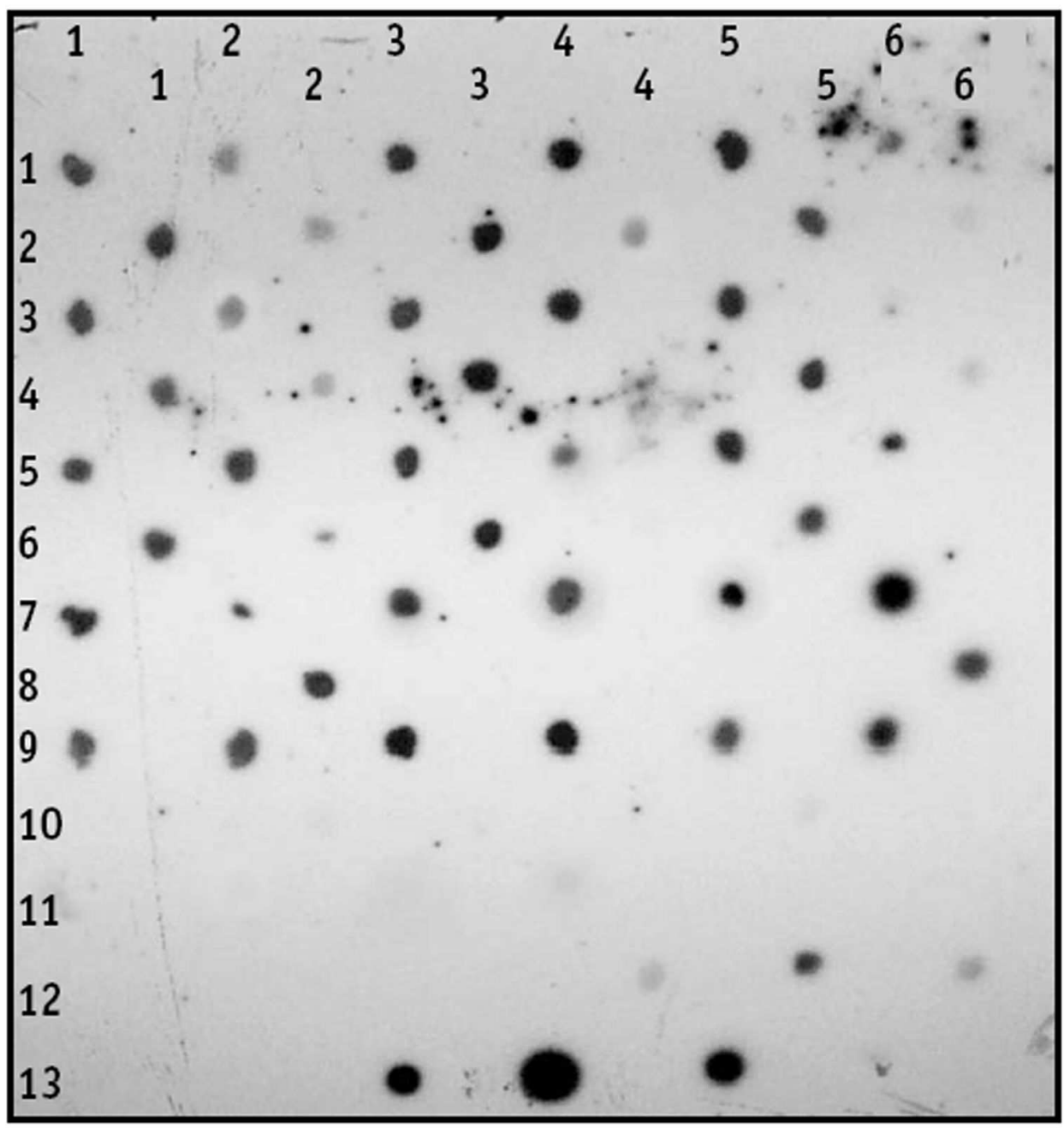

Fig. 1. Dot blot hybridization. DNA of lymphocyte/bacterial DNA $(0.2 \mu \mathrm{g})$ from $27 \mathrm{HIV}$ positive patients are on lines 1-9 and from 9 healthy subjects are on lines 10-12. The PCR products $38 ; 39,68 ; 69$ and mixture, synthesized on the template of patient 30's DNA were used as probes. They are on line 13 in position 3, 4, 5 diluted 1:100.

The PCR specific for HIV sequences was carried out using HIV-1-specific primers. The analysis was performed by colony and dot-blot hybridization using HIV-1-specific primers, which represent gag, pol and env genes of the virus.

\subsection{PCR and sequencing}

Subsequently, bacterial DNA of positive isolates was amplified by the PCR using two sets of primers. The PCR products of $142 \mathrm{bp}$ (primers 68;69, env gene of HIV-1) were detected in all 


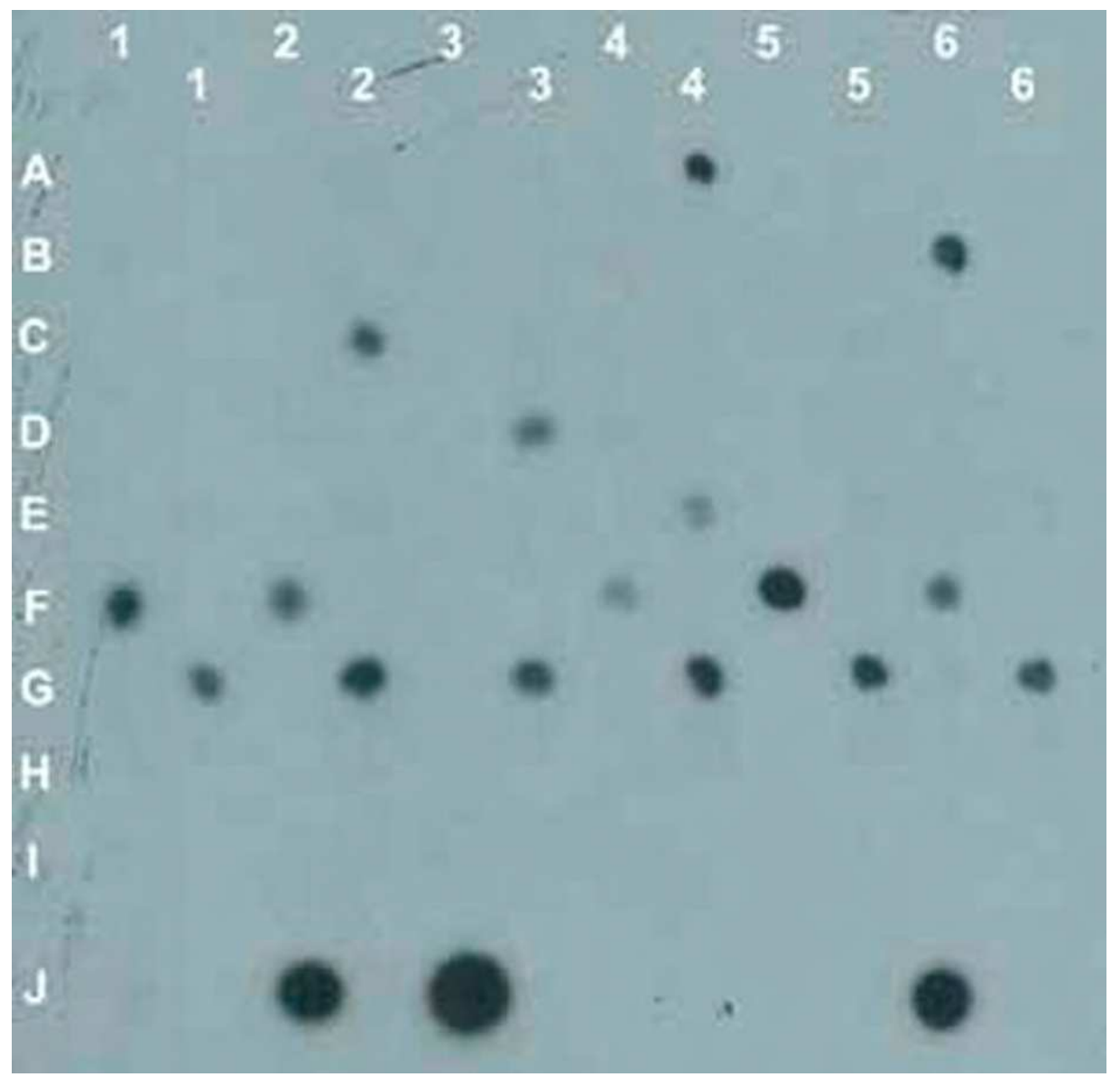

Fig. 2. Dot-blot hybridization of bacterial DNA from Cambodian and Kenyan HIV positive children. Lines A-G: samples of 42 patients; lines H-I: samples of 8 healthy subjects; line J: in position 6 is DNA of AIDS child and in position 2, 3 are probes diluted 1:100 and 1:50.

bacterial samples tested. The longest PCR products of $1484 \mathrm{bp}$ determined by primers P10: CATTTGGAAAGGACCAGCAAAACTACT (HIV-1 pol gene position 4430); E1:TCATATGCTTTAGCATCTGATGCACAA (HIV-1 env gene position 5914) were detected in $70 \%$ of the patient bacterial DNA: M11, P1, P3, P6, P15, P9, M1, M2, M15, M12, M22 (Figure 3).

The PCR products synthesized on the template of bacterial DNA analyzed and on the template of patient's DNA using primers from gag, pol and env genes were sequenced. By sequencing PCR products synthesized on the template of the patients' bacterial DNA using primers 68;69 env HIV-1 gene, 68for: AGCAGCAGGAAGCACTATGG, 69rev: CCAGACTGTGAGTTGCAACAG) homology greater than 90\% with HIV-1 isolate HXB2 (HIVHXB2CG) was revealed. Sequences of intestinal bacteria of patients revealed at least 90\% homology with three crucial HIV-1 genes ( $g a g$, pol, env). Amplified fragments longer than 120 bp were directly sequenced on the ABI 373 DNA Sequencer. 


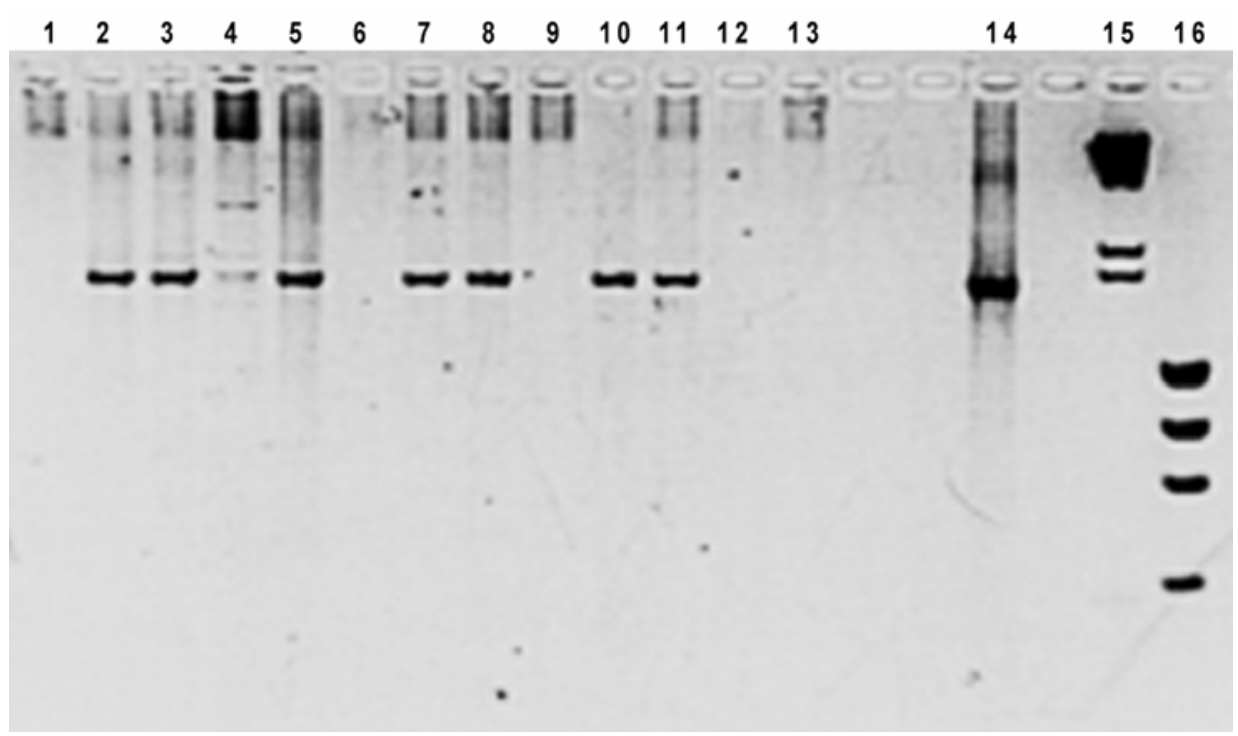

Fig. 3. The PCR products of 1484 bp determined by primers P10for ; E1rev synthesized on the template of bacterial DNA. Lines 1 - 11: AIDS patients; line 12 - PCR without DNA; line 13 - negative control; line 14 - pBH10; line 15 - marker $\lambda$ DNA $\times$ HindIII; line 16 - marker $\phi$ X174×HaeIII.

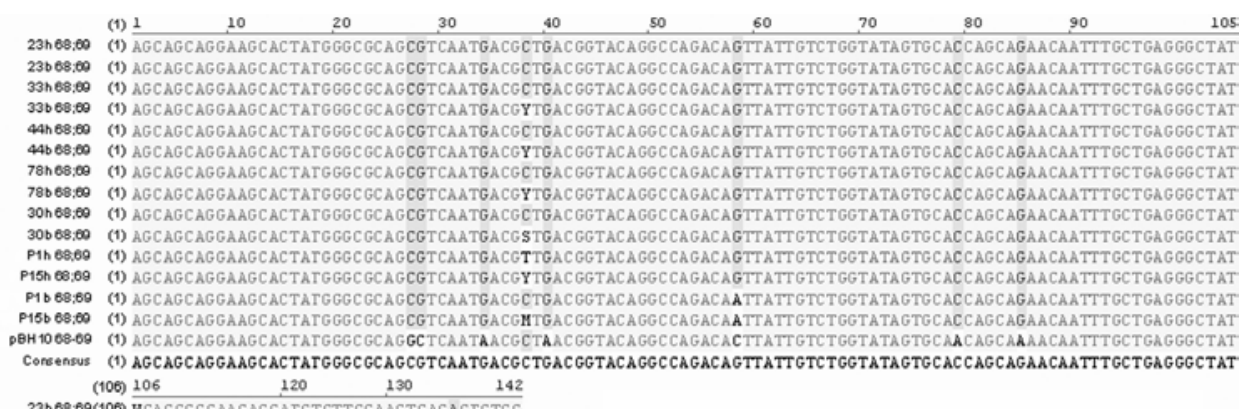

$23 \mathrm{~h} 68,60$ (106) WGAGGCGCAACAGCATCTGTTGCAACTCACAGTCTGG

23668,60(106) AGAGGCGCAACAGCATCTGTTGCAACTCACAGTCTGC

33h 68.69 (106) TGAGGCGCAACAGCATCTGTTGCAACTCACAGTCTGD

33068:09(100) WGAGGCGCAACAGCATCTGTTGCAACTCACAGTCTG

44h 68:69:105) UGAGGCGCAACAGCATCTGTTGCAACTCACAGTCTOG

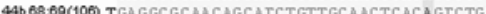

78n68.60(100) WGAGGCGCAACAGCATCTGTTGCAACTCACAGTCTGG

78be8,69(106) WGAGGCGCAACAGCATCTGTTGCAACTCACAGTCTG

30 68;09(106) WGAGGCGCAACAGCATCTGTTGCAACTCACAGTCTG

30b68,60(106) A GAGGCGCAACAGCATCTGTTGCAACTCACAGTCTGC

P1h 68.60 (106) TGAGGCGCAACAGCATCTGTTGCAACTCACAGTCTO

P15h EBO9(100) TGAGGCGCAACAGCATCTGTTCCAACTCACAGTCTGG

P1b $\Theta .69(106)$ TGAGGCGCAACAGCATCTGTTGCAACTCACAGTCTG

P15b $\bullet, 69(106)$ WGAGGCGCAACAGCATCTGTTGCAACTCACAGTCTGG

pEH 106860 (106) TGAGGCGCAACAGCATCTGTTGCAACTCACGGTCTGC

Consenswe (106) GAGGCGCAACAGCATCTGTTGCAACTCACAGTCTGG

Fig. 4. Comparison of the sequences of $142 \mathrm{bp}$ PCR products synthesized on the template of patients' lymphocyte (h) and bacterial (b) DNA, determined by primers 68; 69, of selected patients 23, 33, 44, 78, 30, P1 and P15. Abbreviations: Y - C or T, M - A or C, S - G or C, W A or $\mathrm{T}$. 
The sequences of 142 bp PCR products synthesized on the template of patients' lymphocyte (h) and bacterial (b) DNA, determined by primers 68; 69, were remarkably similar, with some differences occurring between isolates (Figure 4). These minor differences in the isolates strongly suggest that the DNA has a common recent ancestry in HIV-1. Important is the finding of rather marked differences between bacterial sequences and sequences of pBH10 in all fragments tested. On the basis of these results, the possibility of contamination of our samples by $\mathrm{pBH} 10$ plasmid DNA is practically excluded.

\subsection{Protein analysis of patient's bacteria and yeasts}

The expression of HIV-1 antigens in bacteria and yeasts of HIV positive patients was detected by using specific monoclonal antibodies against HIV-1 antigens p17, p24, p55, gp41 and gp120 (Abcam, UK). $55 \mathrm{kDa}$ protein was detected using MAbs against HIV-1 p24 approximately in $30-35 \%$ bacterial extracts of HIV positive Cambodian (Km) and Kenyan (Ke) tested patients: $14 \mathrm{Km}, 31 \mathrm{Km}, 3^{\prime} \mathrm{Km}, 32^{\prime} \mathrm{Km}, 21 \mathrm{Ke}, 17^{\prime} \mathrm{Ke}, 14^{\prime} \mathrm{Ke}$. (Figure 5).

Using MAbs against gp41 the protein of $41 \mathrm{kDa}$ was identified in $30-35 \%$ of bacterial extracts of Cambodian and Kenyan and of American and Slovak patients: P79, PEC, P14, P5, P15, P1. (Figure 6).

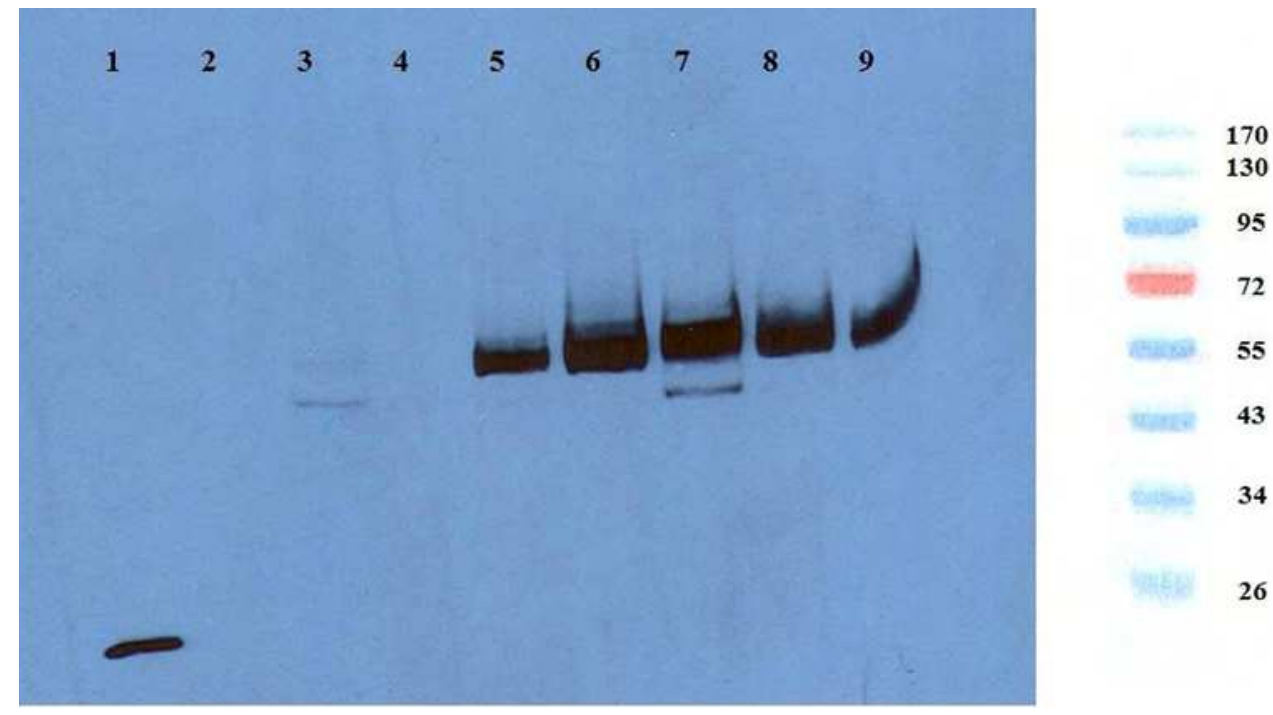

Fig. 5. Western blotting of proteins isolated from bacteria and yeasts of the respiratory tract (nose, pharyngeal swabs) of Cambodian (Km) and Kenyan (Ke) HIV positive children. Detection was performed using monoclonal antibodies against HIV-1 p24. Line 1: p24 diluted 1:500; line 2: control bacteria Muta 104-0; lines 3-9 tested samples.

$55 \mathrm{kDa}$ protein was also detected in bacteria and yeasts from bacteria and yeasts of the respiratory tract (nose, pharyngeal swabs) of Cambodian $(\mathrm{Km})$ and Kenyan (Ke) HIV positive children: $14 \mathrm{Km}, 17^{\prime} \mathrm{Ke}, 21 \mathrm{Ke}, 32^{\prime} \mathrm{Km}, 3^{\prime} \mathrm{Km}, 31 \mathrm{Km}, 14^{\prime} \mathrm{Ke}$, using by MAbs against HIV1 p17, p55 (Figure 7). 


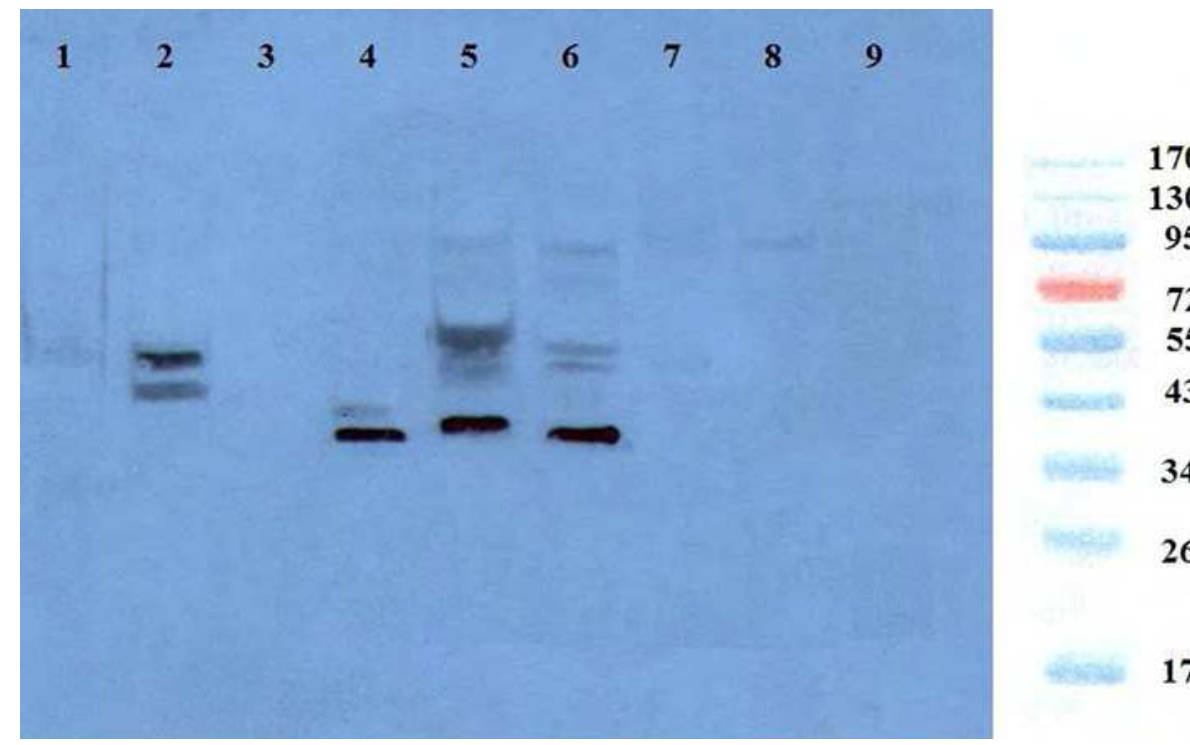

Fig. 6. Western blotting of proteins isolated from intestinal bacteria of Slovak and American HIV positive patients. For detection monoclonal antibodies against HIV-1 gp41 diluted 1:750 were used. Line 1: negative control; line 2: serum of AIDS patient; line 3: control HB101; lines 4-9 tested patients.

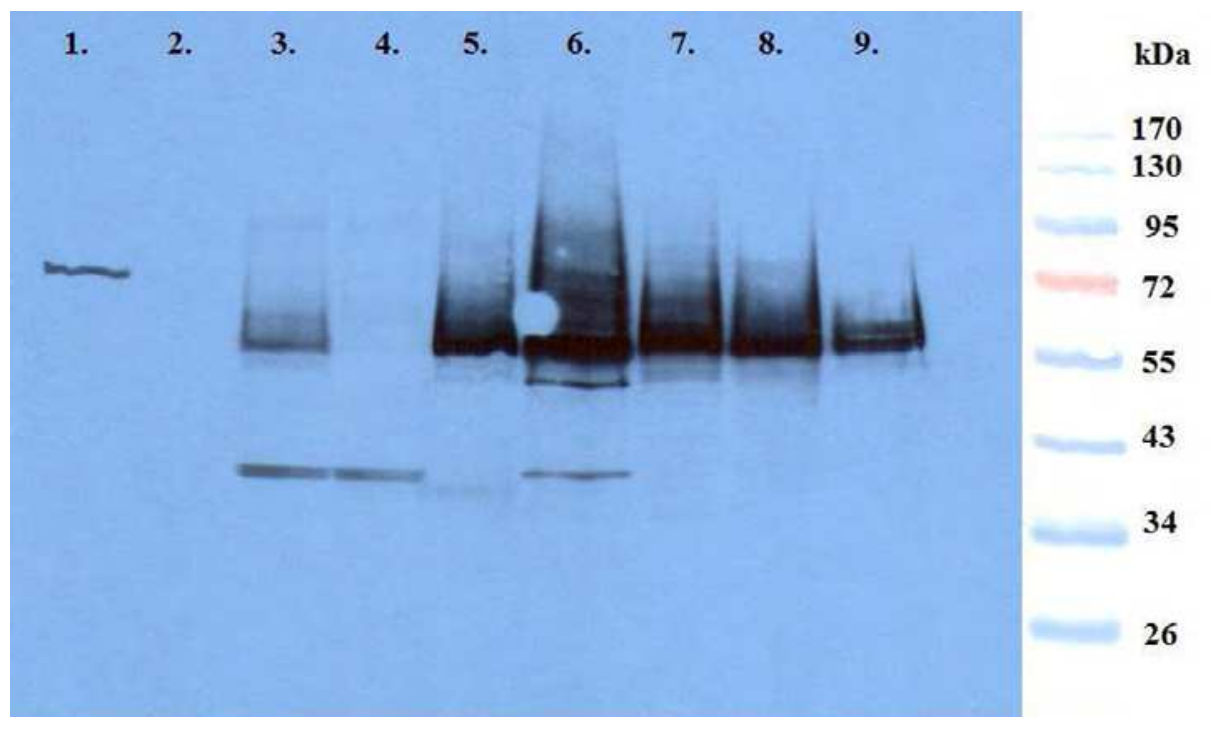

Fig. 7. Western blotting of proteins isolated from bacteria and yeasts of the respiratory tract (nose, pharyngeal swabs) of Cambodian $(\mathrm{Km})$ and Kenyan $(\mathrm{Ke}) \mathrm{HIV}$ positive children.

Detection was performed using monoclonal antibodies against HIV-1 p17, p55 diluted 1:750. Line 1: serum of AIDS patient diluted 1:100; line 2: negative control; lines 3-9 tested samples. 
Using monoclonal antibodies against HIV-1 gp120 (1:750), proteins of 75-80 kDa were detected in protein extracts from bacteria and yeasts of the respiratory tract (nose, pharyngeal swabs) of Cambodian $(\mathrm{Km})$ and Kenyan $(\mathrm{Ke}) \mathrm{HIV}$ positive children: $14 \mathrm{Km}$, $17^{\prime} \mathrm{Ke}, 21 \mathrm{Ke}, 32^{\prime} \mathrm{Km}, 3^{\prime} \mathrm{Km}, 31 \mathrm{Km}, 14^{\prime} \mathrm{Ke}$ (Figure 8).

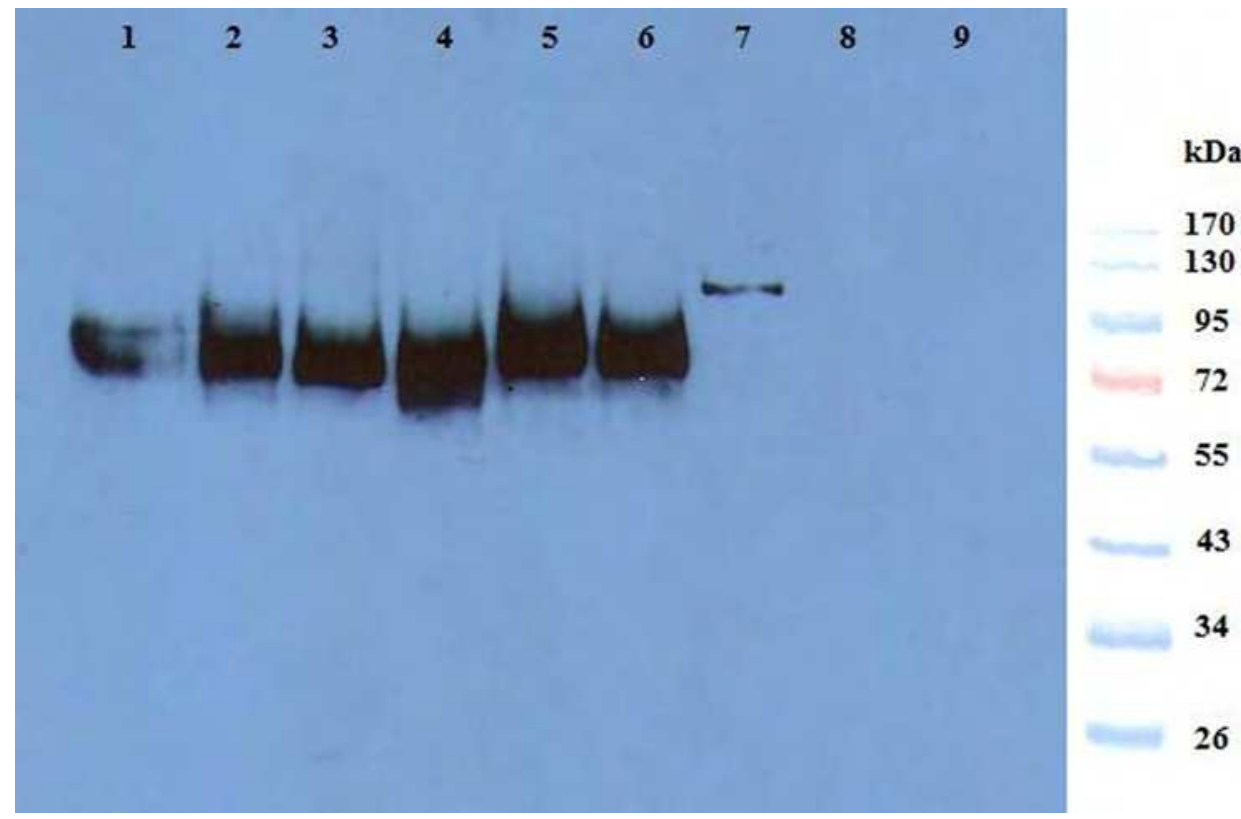

Fig. 8. Western blotting of proteins isolated from bacteria and yeasts of the respiratory tract (nose, pharyngeal swabs) of Cambodian (Km) and Kenyan (Ke) HIV positive children. Used monoclonal antibodies against HIV-1 gp120 (1:750). lines 1-6 tested samples. Line 7: serum of AIDS patient diluted 1:100; line 9: negative control bacteria Muta 104-0.

In samples of Slovak and American HIV positive patients using MAbs against HIV p17, p55 proteins of about $30 \mathrm{kDa}$ was found.

In addition, the protein of molecular weight $55 \mathrm{kDa}$ was detected in Cambodian and Kenyan samples by MAbs anti HIV-1 p17 and p55. Its molecular weight is comparable to gag-encoded Pr55Gag precursor. By MAbs against HIV p24, protein of $55 \mathrm{kDa}$ was found in Cambodian and Kenyan samples. Surprisingly, no proteins were found in bacterial extract of 10 American and 24 Slovak AIDS patients by this MAbs. Protein detected by Mabs against gp41 was identified in $30-35 \%$ of samples from all cohorts of patients. The protein of about $85 \mathrm{kDa}$ was detected only in Candida species protein extracts of Cambodian and Kenyan HIV positive children by the MAbs against gp120. In Slovak and American samples, protein reacting with MAbs anti gp120 was not found. These results suggest that there are specific differences between bacterial proteins of Slovak and American HIV positive patients on one side and Cambodian and Kenyan on the other. These differences suggest a diverse bacterial evolution in various geographical areas. Microbes of Slovak and American HIV/AIDS patients were most often identified as Klebsiella pneumoniae, Escherichia coli, Proteus mirabilis, Citrobacter freundii and Enterobacter 
aerogenes. Microbes from respiratory tract of Cambodian and Kenyan HIV/AIDS patients were most often identified as Staphylococcus aureus, Klebsiella pneumoniae, Candida albicans, Candida tropicalis, Enterobacter aerogenes, but also as Escherichia coli and Proteus mirabilis.

\subsection{Tests for internalization capacity of patient's bacteria}

The obtained results raise the question, what is the role of intestinal bacteria bearing HIV sequences in the AIDS process (Simon \& Gorbach, 1984). Analogous to the finding of Swidsinski (Swidsinski et al., 1998, 2002) and our previous works (Mego et al., 2005, 2006) that bacteria isolated from biopsies of polyps, adenomas, and carcinomas are able to internalize epithelial cells, we tested bacteria purified from the intestinal tract of Slovak and American HIV/AIDS patients for their capacity to be internalized by cells of HL-60 cell line and normal human lymphocytes. In the present study, the specific characteristic was found to be their vigorous ability to be internalized by HL-60 cells and human lymphocytes, as confirmed by a gentamicin protection assay. In comparison with intramucosal bacteria isolated from patients with colorectal cancer, their capacity to be internalized by normal human lymphocytes was 510 times higher and in most cases the cells were lysed. Bacteria 725/5 were classified as Enterobacter cloacae and all other clones tested were characterized as Escherichia coli. Internalization frequently resulted in partial (bacteria of patients M1, M22) or complete lysis (patients K1, M12) of HL-60 cells. Partial (patients P3, M22) and complete lysis (patients P1, K1, M1, M12) was detected also after infection of normal human lymphocytes.

What is the fate of bacteria after internalization? As we demonstrate, about $50-60 \%$ of the bacteria of tested AIDS patients are competent to lyse HL-60 and lymphocytes of host cells. The remaining part of intracellular bacteria survived in the host cells for a further 7-10 days, as shown by GPA. After this time the GPA test was negative. It can be assumed that in nature some pathogenic bacteria which penetrated into the blood system may infect or lyse lymphatic cells.

\begin{tabular}{cc}
\hline Patient/bacterial clone & Number of bacterial colonies \\
P15/7 & HIV positive patients \\
P1/4 & 2264 \\
P3/3 & 1340 \\
$725 / 5$ & 1680 \\
M1/6 & 1140 \\
M22/5 & 27/ partial lyses of HL-60 cells \\
M12/5 & complete lyses of HL-60 cells \\
K1/1 & complete lyses of HL-60 cells \\
& \\
TuSG/1 & 71 \\
883 S/3 & 104 \\
MZRa/3 & 44 \\
negative controls (healthy subjects) & $<5$ \\
\hline
\end{tabular}

Table 1. Gentamicin protection assay. The number of colonies represents the number of intracellular bacteria in HL-60 cells. Number of cells used for assay: HL-60 5x106 ; bacteria $1 \times 10^{8}$ 


\begin{tabular}{cc}
\hline Patient/bacterial clone & Number of bacterial colonies \\
P15/7 & 1121 \\
P3/3 & HIV positive patients \\
$725 / 5$ & $320 /$ partial lysis of human lymphocytes \\
M22/5 & 1140 \\
P1/4 & $423 /$ partial lyses of human lymphocytes \\
K1/1 & complete lyses of human lymphocytes \\
M1/6 & complete lyses of human lymphocytes \\
M12/5 & complete lyses of human lymphocytes \\
& complete lyses of human lymphocytes \\
TuSG/1 & 1 \\
883 S/3 & 0 \\
MZRa/3 & 4 \\
negative controls (healthy subjects) & $<5$ \\
\hline
\end{tabular}

Table 2. Gentamicin protection assay. The number of colonies represents the number of intracellular bacteria in normal human lymphocytes. Number of used cells: normal human lymphocytes $1,5 \times 10^{7}$; bacteria $1 \times 10^{8}$.

To analyze the role of bacteria in immunodeficiency, reduction of their amount in the intestinal tract of 20 AIDS patients was performed by oral administration of probiotic bacteria Escherichia coli strain Nissle 1917. After three months of probiotics treatment the viral load decreased or remained on the detection limit $(<400 \mathrm{c} / \mathrm{ml})$ in $55.5 \%$ of the patients tested. According to these findings, it is assumed that not only one biological component plays the most important role in the AIDS process, but that there are two - HIV and the bacterial host. These bacteria bearing rich extrachromosomal genetic information are able to penetrate from the GIT into the human body and attack strongly the human immune system.

\section{Etiology and possible evolution of disease}

The fundamental, still unanswered question is the origin of HIV (Gallo et al., 1985; Baltimore, 1985; Duesberg, 1987; Temin, 1988, 1989; Varmus, 1989; Sharp et al., 2001; Zhu et al., 1998; Apetrei \& Marx, 2005). Is HIV a unique relative of other retroviruses? When looking at retroviruses, the rule applies that practically every species in the animal kingdom has its own retrovirus - mouse, rat, chicken, goat, sheep, cow, horse, monkey, chimpanzee, etc. Some of them are very contiguous, due to their phylogenetic relationship - mouse and rat, monkey and chimpanzee. Similarly, retroviruses of monkeys, chimpanzee and humans are evolutionarily collateral. Yet there is no substantial evidence about transmission of retroviruses between different species in nature. On the basis of these facts and our achieved results, it is possible to conclude - all retroviruses have been an integral part of a particular host organism since the beginning of their existence as species and they are passed on from generation to generation. The hosts - including humans - inherited them from their ancestors. In accordance with this idea, it is assumed that transfer of the HIV from apes to humans in Africa, as a consequence of their accidental contacts, is not the cause of AIDS pandemics. 
But there is a very serious objection - if HIV were in our bacteria from our beginning, why did they emerge only about 25-35 years ago? Were they hidden without any implication all the time, for many thousands of years, in our bodies? To answer this question, we should go back into the ancient history of humankind. In the past, major epidemics frequently occurred when there were new patterns of communication and transportation between separately populated areas and/or new patterns of settlement. The first recorded great plague occurred in Athens during the Peloponnesian war in $430 \mathrm{BC}$. In the middle of the sixth century AD (542), there was a great outbreak of bubonic plague (Justinianus) in the Mediterranean countries, where 40 to $50 \%$ of the population died. The biggest cataclysm of bubonic plague epidemic started in 1346 in Europe and the population was finally decimated by 50 to $60 \%$. Plague subsequently spread to Asia and at least 60 million people died just only in China alone. This plague continued up to the seventeenth and partially to the eighteenth century. In the sixteenth century, after Europeans reached America, new devastating epidemics started among the native peoples resulting in a $90 \%$ population loss among American Indians within 120 years.

Who were in particular the victims of these plagues? Mostly people who were malnourished, sick, with a debilitated immune system. As discussed above, bacteria carrying the rich extra-chromosomal genetic information, as plasmids, phages, transposomes, viruses and virus-like particles (HIV included), are mostly pathogenic for the host organism and continually attack the immune system after penetration. This attack depends on the amount of the microbes which penetrate into the blood. Thus the immune system of people with low amounts of these bacteria was stronger and their carriers had a chance to overwhelm any plague. One of the most important results of the set of plagues that occurred in the history of humankind, mainly in Europe, North Africa, North America and partially in Asia, was natural selection, resulting in sanitation of the human population. Hand in hand in this tremendous evolution process was the selection of people with a low level of bacteria carrying pathogenic, mainly extra-chromosomal genetic information, able to penetrate into the human body and attack the immune system. The outcome of this complex evolutional proceeding, which finished towards the end of the nineteenth century, was a great reduction of pathogenic bacteria in the human population and eventually the establishment of a balance between non-pathogenic and pathogenic ("good" and "bad") microbes in the microflora of surviving individuals. The effect of this process was limitation of bacteria bearing HIV sequences and the selection of people carrying CCR-5 receptor deficiency on white blood cells.

A consequence of many plagues in the history of mankind was the establishment of a balance between prokaryotic and eukaryotic kingdoms in our body, which led to a positive selection of people with a low amount of viral and retroviral genetic information in their intestinal bacteria. This tremendous process, whose victims were many millions of humans, was very intensive particularly in Europe. The stability, acquired over many centuries, between eukaryotic and prokaryotic kingdoms was interrupted in the middle of the twentieth century due to the use of antibiotics, narcotic drugs and changes in life style (homo and anal sex).

It is generally accepted that due to ATB practically all primary bacterial pathogens were liquidated throughout two-three decades. The success of antibiotics in elimination of many diseases induced by microbes was such expressive that in the mid-1950s US Surgeon General Steward effusively proclaimed that the era of bacterial diseases finished. This trend 
of ATB glorification was spread very quickly from USA to Europe and microbiology got to the scientific periphery. In 1969, only a few people heard the voice of the English scientist J. A. Reaburn who said that in the future years it would be shown that antibiotics could bring us unforeseen vicious tricks.

In this way resistant, potentially pathogenic microbes, bearing rich extra-chromosomal genetic information as plasmids, phages, transposomes, virus-like particles (VLP) or viruses (including HIV), went from minority to majority and attacked the human immune system. Microbes employed their ability to change their shape - cell wall deficient (CWD) to survive in these hard conditions or were internalized into host cells (Swidsinski et al., 1998, 2002; Martin et al., 2004; Beachey, 1981; Benjamin et al., Cohen \& Laux, 1995). Some of these microbes are able to overcome insurmountable barriers existing between microbial DNA and DNA of more highly organized beings. The result of this process are health troubles and one of them, induced by HIV bacteria with strong affinity to $\mathrm{T}$ lymphocytes, is immunodeficiency.

This proceeding started between Afro-American drug users because they had not been going through plague selection and sanitation, as had other American inhabitants. Disease spread mainly in big American cities as Los Angeles, San Fransisco, New York, Chicago, and others. Microbes which might be harmless in a healthy body became deadly in conjunction with drugs. This hypothesis was put forward in an editorial of the New England Journal of Medicine by David Durack: Some new factors may have distorted the host-parasite relation. So-called "recreational" drugs are one possibility. They were widely used in the large cities where the most of these cases have occurred, and the only patients in the series reported with this issue who were not homosexual were drug users. Perhaps one of these recreational drugs is an immunosuppressive agent (Durack and Phil, 1981). The leading candidates were nitrites, which were commonly inhaled in the years 1960 to 1977 to intensify orgasm. Butyl nitrite very probably plays an important role in induction of Kaposi's sarcoma in AIDS (Mirwish \& Hawerkos, 1987). Mice exposed to isobutyl nitrite showed dose-related immune system damage and became highly susceptible to disease and death caused by mycobacterial infection (Neefe et al., 1983).

The "classical" drugs have a similar but more intensive effect on the immune system and micro-flora of drug users. The elimination of "good" intestinal bacteria by continually used drugs opened the space for amplification of microbes, which had existed before in the minority. The result of this process is that the immune system is not able to react to the massive attack and many diseases are induced, as: pneumonia, tuberculosis, toxoplasmosis, Cryptococcus, hepatitis B, herpes simplex, cytomegalovirus, bacterial, yeast and fungal infections, lymph gland infections and immunodeficiency. Amplified pathogenic microbes are equipped with antibiotic resistance and some of them are bearing viral and retroviral genetic information. Many of these infections are chronic or recurring, often unrecognized at first, and difficult to treat. Consequent antibiotic treatment forwards the spiral process of natural micro-flora destruction. And finally, ingestion of antiretroviral drugs as AZT completed this distortion. The result of such continual, step by step attack of intestinal microbes is their unification, reduction of their heterogeneity and loss of their basic function for the host. In the intestinal tract of two American AIDS patients in the final phase we found only one type of bacteria bearing HIV-1 sequences - multi-resistant Escherichia coli with plasmids of about $50 \mathrm{kbp}$. 


\section{Conclusion}

Hypothetically, bacteria are probably hosts not only for HIV but also for other retroviruses. The presence of HIV sequences in commensurate bacteria of the patients may be explained as follows: 1) intestinal bacteria were infected by HIV or virus-like particles (VLP) previously produced by human cells, in particular by macrophages and lymphocytes; 2) intestinal bacteria of AIDS patients are a natural host of HIV sequences in the form of a virus or VLP.

Effective vaccines for human immunodeficiency virus type 1 (HIV-1) will have to stimulate protective immunity in the intestinal mucosa, where HIV-1 infection causes severe CD4 ${ }^{+} \mathrm{T}-$ cell depletion (Bealshe et al., 1994; Bartlett et al., 2003). While replication-competent recombinant adenovirus ( $\mathrm{rAd}$ ) vectors can stimulate adenovirus-specific mucosal immunity after replication, oral delivery of replication-defective rAd vectors encoding specific immunogens has proven challenging (Wang et al., 2009).

Recent studies suggest that induction of primary immune responses by recombinant bacterial vectors leads to gut immunization and subsequent systemic boosting elicits potent antigen-specific gut mucosal responses. Genetically modified bacteria have been experimentally used as recombinant probiotics also in gastrointestinal disorders, but clinical usage is currently not the case. Nevertheless, in the future a greater use of this kind of approach is expected. The expression of HIV-1 antigens in specific probiotic strains may be suitable for clinical use as a potential vaccine.

\section{Acknowledgement}

We would like to thank Danica Stanekova and all the people working at HIV/AIDS Reference Centre, Slovak Medical University, Bratislava, to Milos Mokras from Department of Infectious Diseases and Geographic Medicine, Derer's Hospital, Bratislava and to Vladimir Krcmery from St. Elizabeth University, Bratislava for patient's samples.

This work was supported by the grant VEGA 2/5025/27, 2/0081/08 and the grant APVV0404-07.

\section{References}

Apetrei, C., and Marx, P.A. (2005). African lentiviruses related to HIV. J. Neurovirol. 11: 3349.

Baltimore, D. (1985). Retroviruses and retrotransposos: The role of reverse transcription in shaping the eukaryotic genome. Cell 40: 481-482,

Bartlett, J.G., Carlos, del Rio, DeMaria, A., Sepkowitz K.A. (2003). Smallpox Vaccination and the HIV-Infected Patient: A Roundtable. AIDS Clinical Care, 15: 61-63.

Belshe, R.B., Bolognesi, D.P., Clements, M.L., Corey, L., Dolin, R., Mestecky, J., Mulligan, M., Stablein, D., Wright, P. (1994). HIV infection in vaccinated volunteers. JAMA, 10: 431.

Beachey, E.H. (1981). Bacterial adherence: adhesin-receptor interactions mediating the attachment of bacteria to mucosal surface. J. Infect. Dis., 143: 325-345.

Benjamin, P., Federman, M., and Wanke, Ch.A. (1995). Characterization of an invasive phenotype associated with enteroaggregative Escherichia coli. Infection and Immunity, 63: 3417-342. 
Brenchley, J.M., Schacker, T. W., Ruff, L.E., Price, D.A., Taylor, J.H., Beilman, G.J., Nguyen, P.L., Khoruts, A., Larson, M., Haase, A.T., Douek, D. (2004). CCD4+T Cell Depletion during all Stages of HIV Disease Occurs Predominantly in the Gastrointestinal Tract. Journal of Experimental Medicine, 200: 749-759.

Broxmeyer, L., and Cantwell, A. (2008). AIDS: "It's the bacteria, stupid!" Medical Hypotheses, 71, 741-748.

Cantwell Jr AR. (1983). Kaposi's sarcoma and variably acid-fast bacteria in vivo in two homosexual men. Cutis, 32(1): 58-61.

Cantwell Jr AR. (1993). Necroscopic findings of variably acid-fast bacteria in a fatal case of acquired immunodeficience syndrome and Kaposi's sarcoma. Growth, 47(2):129-34.

Cusini M., Salmaso F, Zerboni R, Carminati G, Vernaci C, Franchi C, Locatelli A, Alessi E. (2004). 5\% Imiquimod cream for external anogenital warts in HIV infected patients under HAART therapy. Int J STD AIDS, 15: 17-20.

Cohen, P.S., and Laux, D.C.(1995). Bacterial adhesion to and penetration of intestinal Mucus in vitro. Methods Enzymol., 253: 309-314.

Dandekar, S. (2007). Pathogenesis of HIV in the gastrointestinal tract. Curr HIV/AIDS Rep. 4 (1):10-15.

Duesberg, P.H.(1987). Retroviruses as Carcinogens and Pathogens: Expectations and Reality. Cancer Research, 47: 1199-1220.

Durack, D.T., Phil, M.B.D. (1981). Opportunistic Infections and Kaposi's Sarcoma in Homosexual Men. New England Journal of Medicine, 305:1465-1467.

Finzi, D., Hermankova, M., Pierson, T., Carruth, T.L., Buck, C., Chaisson, R.E., Quinn, T.C., Chadwick, K., Margolick, K.J., Brookmeyer, R., Gallant, J., Markowitz, M., Ho, D.D., Richman, D.D., Siliciano, R.F. (1997). Identification of a Reservoir for HIV-1 in Patients on Highly Active Antiretroviral Therapy. Science, 278: 1295-1300.

Gallo, R.C., and Wong-Staal, F. (1985). A human T-lymphotropic retrovirus (HTLV-III) as a the cause of the acquired immunodeficiency syndrome. Ann.Intern. Med., 103:679689.

Guadalupe, M., Sankaran, S., George, M.D., Reay, E., Verhoeven, D., Shacklett, B.L., Flamm, J., Wegelin, J., Prindiville, T., Dandekar, S. (2006). Viral suppression and immune restoration in the gastrointestinal mucosa of human immunodeficiency virus type1-infected patients initiating therapy during primary or chronic infection. J. Virol., 80: 8236-47.

Hatziioannou, T., Ambrose, Z., Chung, N.P., Piatak, M. Jr, Yuan, F., Trubey, C.M., Coalter, V., Kiser, R., Schneider, D., Smedley, J., Pung, R., Gathuka, M., Estes, J.D., Veazey, R.S., KewalRamani, V.N., Lifson, J.D., Bieniasz, P.D. (2009). A macaque model of HIV-1 infection. Proc Natl Acad Sci U S A., 17; 106 (11):4425-9.

Chun,T.W., Davey, R.T., Ostrowski, M., Shawn, J.J., Engel, D., Mullins, J.I., and Fauci, A.S. (2000). Relationship between pre-existing viral reservoirs and the re-emergence of plasma viremia after discontinuation of highly active anti-retroviral therapy. Nature Medicine, 6:757-61.

Lackner, A.A., Mohan, M., Veazey, R.S. (2009).The gastrointestinal tract and AIDS pathogenesis. Gastroenterology, 136(6):1965-78.

Li, Q.S., Duan, L.J., Estes, J.D., Ma, Z.M., Rourke, T., Wang, Y.CH., Reilly, C., Carlis, J., Miller, CH.J., Haase, A.T. (2005). Peak SIV replication in resting memory CD4 ${ }^{+} \mathrm{T}$ cells depletes gut lamina propria CD4+ T cells. Nature; 434:1148-52. 
Ling, B., Veazey, R.S., Hart, M., Lackner, A.A., Kuroda, M., Pahar, B., Marx, P. (2007). Early restoration of mucosal CD4 memory CCR5 T cells in the gut of SIV-infected rhesus predicts long term non-progression. AIDS, 21(18):2377-85.

Ling, B., Mohan, M., Lackner, A.A., Green, L.C., Marx, P.A., Doyle, L.A., Veazey, R.S. (2010). The large intestine as a major reservoir for simian immunodeficiency virus in macaques with long-term, nonprogressing infection. J Infect Dis., 202(12): 1846-54.

Lo, S.-C., Tsai, S., Benish, J.R., Shih, J.W.-K., Wear, D.J., and Wong, D.M. (1991). Enhancement of HIV-1 cytocidal effects in $\mathrm{CD}_{4}{ }^{+}$lymphocytes by the AIDSassociated mycoplasma. Science, 251: 1074-1076.

Martin, M.H., Campbell, B.J., Hart, C.A., Mpolfu, C., Nayar, M., Singh, R., Englyst, H., Williams, H.F., Rhodes, J.M. (2004). Enhanced Esherichia coli adherence and invasion in Crohn's disease and colon cancer. Gastroenterology,127: 80-93.

Mattapallil, J.J., Daniel, C., Douek, D.C., Hill, B., Nishimura, Y., Martin, M., Roederer, M. (2005). Massive infection and loss of memory $\mathrm{CD}^{+}{ }^{+} \mathrm{T}$ cells in multiple tissues during acute SIV infection. Nature, 434: 1093-7.

Mego, M., Majek, J., Koncekova, R., Ebringer, L., Ciernikova, S., Rauko, P., Kovac, M ., Trupl, J., Slezak, P., Zajac, V. (2005). Intramucosal bacteria in colon cancer and their elimination by probiotic strain Enterococcus faecium M-74 with organic selenium. Folia Microbiologica, 50: 443-447.

Mego,M., Koncekova, R., Mikusova, E., Ebringer, L., Demitrovicova, L., Nemova, I., Drgona, L., Trupl, J., Mardiak, J., Koza, I., Zajac, V. (2006). Prevention of febrile neutropenia in leukemic patients by probiotic strain Enterococcus faecium M-74. Phase II.study. Support Care Cancer, 14, 285-290.

Mirwish, S.S., Hawerkos, H.W.(1987). Butyl nitrite in induction of Kaposi sarcoma in AIDS. ]. New England Journal of Medicine, 17: 1603.

Montagnier, L.: Vaincre le SIDA. (1986). Entretiens avec Pierre Bourget. Paris, Editations Cana.

Neefe, J.R., Ganjii, A., and Goedert, J.G. (1983) “Daily Amyl Nitrite Inhalation Decreases Mouse Splenocyte Response to Concanavalin A". (abstract 3850) Federation Proceedings 42 (4): 949, 5 March.

Nelson, J.A., Wiley, C.A., Reynolds-Kohler, C., Reese, C.E., Margaretten, M., Lecy, J.A. (1988). HIV detected in bowel epithelium from patients with gastrointestinal symptoms. Lancet, 6: 259-62.

Sharp, P.M., Bailes, E., Chaudhui, R.R., Rodenburg, C.M., Santiago, M.O., Hahn, B.H. (2001). The origin of acquired immune deficiency syndrome viruses: where and when? Philos Trans R Soc Lond B Biol Sci., 29: 867-876.

Siliciano, J.D., Kajdas, J,, Finzi, D.C., Quinn, T.C., Chadwick, C., Margolick, J.B., Kovacs, C., Gange, S.J., and Siliciano, R.F. (2003). Long-term follow-up studies confirm the stability of the latent reservoir for HIV-1 in resting CD4+ T cells. Nature Medicine, 9: 727-8.

Simon, G.L., and Gorbach, S.L. (1984). Intestinal microflora in health and disease. Gastroenterology, 86: 174-193.

Swidsinski, A., Khilkin, M., Kerjaschki, D., Schreiber, S., Ortner, M., Weber, J., Lochs, H. (1998). Association between intraepthelial Escherichia coli and colorectal cancer. Gastroenteology, 115; 281-286. 
Swidsinski, A., Ladhoff, A., Pernthaler, A., Swidsinski, S., Loening-Baucke, V., Orther, M., Weber, J., Hoffman, U., Schrei-Ber, S., Dietel, M., Lochs H. (2002). Mucosal flora in inflammatory bowel disease. Gastroenterology 122, 44-54.

Temin, H.M. (1988). Origin of retroviruses from cellular moveable genetic elements. Cell, 21: $599-600$.

Temin, H.M. (1989). Retrons in bacteria. Nature, 39: 254-255.

Varmus, H.J. (1989). Reverse transcription in bacteria. Cell , 56: 721-724.

Veazey, R.S., DeMaria, M.A., Chalifoux, L.V., Shvetz, D.E., Pauley, D.R., Knight, H.L., Rosenzweig, M., Johnson, R.P., Desrosiers, R.C., Lackner, A.A. (1998). Gastrointestinal tract as a major site of CD4+ T cell depletion and viral replication in SIV infection. Science, 280: 427-31.

Veazey, R.S., Lackner, A.A. (2005). HIV swiftly guts the immune system. Nature Medicine, 11: $469-70$.

Wang, L.S., Cheng, Ch., Ko, S.Y., Kong, W-P., Kanekiyo, M., Einfeld, D., Schwartz, R.M., C. Richter King, R., Gall, J.G.D. and Nabel, G.J. Delivery of Human Immunodeficiency Virus Vaccine Vectors to the Intestine Induces Enhanced Mucosal Cellular Immunity. J. Virol. 2009: 83: 7166-7175.

Zajac, V., Kovac, M., Ciernikova, S., Mego, M., Rauko, P., Stevurkova, V., Stanekova, D., and Mokras, M. (2005). Detection of HIV sequences in colon bacteria of AIDS positive patients. ECCMID conference Clin. Microbiol. Infec. 11: 53, Copenhagen, April 2005.

Zajac, V., Stevurkova, V., Matelova, L., Ujhazy, E. (2007). Detection of HIV-1 sequences in intestinal bacteria of HIV/ AIDS patients. Neuroendocrinology Letters, 28: 591- 595.

Zajac,V., Mego, M., Kovac, M., Stevurkova, V., Ciernikova, S., Ujhazy, E., Gajdosik, A., Gajdosikova A.(2006). Testing of bacteria isolated from HIV/AIDS patients in experimental models. Neuroendocrinology Letters, 27: 101-104.

Zajac, V., Matelova, L., Liskova, A., Mego, M., Holec, V., Adamcikova, Z., Stevurkova, V., Shahum, A., Krcmery, V. (2011). Confirmation of HIV-like sequences in respiratory tract bacteria of Cambodian and Kenyan HIV-positive pediatric patients. Medical Science Monitor, 17(3):154-158.

Zhu, T., Korber, B.T., Nahmias, A.J., Hooper, E., Sharp, P.M., Ho, D.D. (1998). An African HIV-1 sequence from 1959 and implications for the origin of the epidemic. Nature, 391: 594-7. 


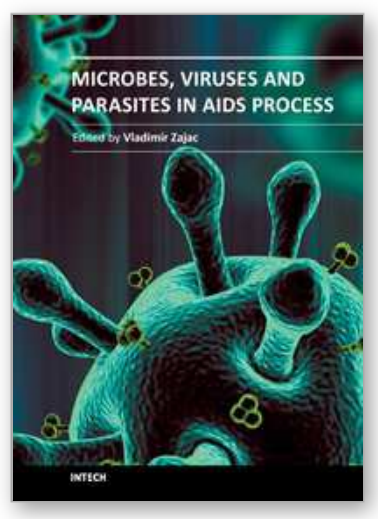

\author{
Microbes, Viruses and Parasites in AIDS Process \\ Edited by Prof. VladimÃr Zajac
}

ISBN 978-953-307-601-0

Hard cover, 390 pages

Publisher InTech

Published online 19, October, 2011

Published in print edition October, 2011

The main goal in compiling this book was to highlight the situation in Africa in terms of AIDS and opportunistic diseases.Â Several chapters reveal great poverty, an apocalyptic situation in many parts of Africa.Â Global migration of people resulted in their exposure to pathogens from all over the world. This fact has to be acknowledged and accepted as African reality. New, unconventional hypotheses, not determined by established dogmas, have been incorporated into the book, although they have not yet been sufficiently validated experimentally.Â It still applies that any dogma in any area of science, and medicine in particular, has and always will hinder progress. According to some biologists, in the future, AIDS is very likely to occur in a number of variations, as a direct result of the ongoing processes in the global human society. Thus, we urgently need a comprehensive solution for AIDS, in order to be ready to fight other, much more dangerous intruders.

\title{
How to reference
}

In order to correctly reference this scholarly work, feel free to copy and paste the following:

Vladimír Zajac, Zuzana Adamcikova, Vladimir Holec, Katarina Hainova, Viola Stevurkova, Lenka Wachsmannova and Vladimir Krcmery (2011). The Role of Bacteria and Yeasts in AIDS, Microbes, Viruses and Parasites in AIDS Process, Prof. VladimÃr Zajac (Ed.), ISBN: 978-953-307-601-0, InTech, Available from: http://www.intechopen.com/books/microbes-viruses-and-parasites-in-aids-process/the-role-of-bacteria-andyeasts-in-aids

\section{INTECH}

open science | open minds

\section{InTech Europe}

University Campus STeP Ri

Slavka Krautzeka 83/A

51000 Rijeka, Croatia

Phone: +385 (51) 770447

Fax: +385 (51) 686166

www.intechopen.com

\section{InTech China}

Unit 405, Office Block, Hotel Equatorial Shanghai

No.65, Yan An Road (West), Shanghai, 200040, China

中国上海市延安西路65号上海国际贵都大饭店办公楼 405 单元

Phone: +86-21-62489820

Fax: $+86-21-62489821$ 
(C) 2011 The Author(s). Licensee IntechOpen. This is an open access article distributed under the terms of the Creative Commons Attribution 3.0 License, which permits unrestricted use, distribution, and reproduction in any medium, provided the original work is properly cited. 